\title{
FUNK OSTENTAÇÃO: DO INCENTIVO AO CONSUMO DE MARCAS DE LUXO ÀS FALSAS PROMESSAS DE INCLUSÃO E STATUS SOCIAL
}

FUNK OSTENTATION: FROM THE INCENTIVE TO THE CONSUMPTION OF LUXURY TRADEMARKS TO

FALSE PROMOTIONS OF INCLUSION AND SOCIAL STATUS

Robson da Silva Constante1, Saraí Patrícia Schmidt²

\author{
Recebido em: 27 de novembro de 2016 \\ Aprovado em: 10 de abril de 2017 \\ Sistema de Avaliação: Double Blind Review \\ RCO | a. 9 | v. 2 | p. $26-36$ | jul./dez. 2017
}

\begin{abstract}
RESUMO
As músicas do gênero funk ostentação vêm ganhando destaque na mídia brasileira. Suas letras carregam os nomes de diversas marcas de grifes nacionais e internacionais, e direcionam para o consumo dessas marcas globalizadas com o intuito de vender um estilo de vida e normas de comportamento para nossa sociedade contemporânea. O gênero musical da ostentação, portanto, é o foco do estudo. Analisa-se o discurso pronunciado em duas letras de músicas. Em uma delas - Nós de nave - fica evidenciada a falsa promessa de inclusão social. Incentiva-se o consumo desenfreado de produtos de luxo pelo público-alvo para o qual esse nicho musical é voltado: a juventude. Seu mote é a ideia de que a desigualdade social pode ser amenizada quando adquiridos os produtos de luxo das marcas famosas. Já a outra letra intitulada Resposta ao funk ostentação -, de autoria de Edu Krieger, ganha destaque justamente por recriminar, a cada verso, a alusão à cultura do consumo por meio da ostentação do luxo e abordar seus impactos na cultura e na identidade juvenil.
\end{abstract}

Palavras-chaves: Funk ostentação. Consumo. Marcas de luxo. Inclusão social.

\begin{abstract}
The songs of the genre funk ostentation have been gaining prominence in the Brazilian media. His lyrics carry statements of several brands of national and international brands, which govern to a consumption of globalized brands with the intention of selling a lifestyle or way of being in our contemporary society. The ostentation genre will be the focus of study, in which it will analyze the speeches pronounced in two letters of songs of the genre. One of the lyrics is evidenced a "false promise" of social inclusion, when they encourage an unbridled consumption of luxury products, especially to the target audience where the musical rhythms are directed. The other lyrics are highlighted in this study, titled "Response to funk ostentation" by Edu Krieger, in which he reproaches each verse of his song for an allusion to a culture of consumption through the ostentation of luxury, and the Impacts on youth culture and identity by encouraging the consumption of luxury brands as a form of social status and guaranteeing a false social inclusion. The song lyrics for Mc Boy do Chame gain musical intonation when he recounts in his verses that social inequality can be achieved when he boasts the power of money in the conquest of luxury products / brands and famous brands.
\end{abstract}

Keywords: Ostentation funk. Consumism. Luxury brands. Social inclusion.

\footnotetext{
1 Doutor em Diversidade Cultural e Inclusão Social pela Universidade Feevale (Novo Hamburgo/Brasil). E-mail: robsonconstante@bol.com.br.

${ }^{2}$ Doutora em Educação pela Universidade Federal do Rio Grande do Sul (Porto Alegre/Brasil). Professora na Universidade Feevale (Novo Hamburgo/Brasil). E-mail: saraischmidt@ feevale.br.
} 


\section{INTRODUÇÃ̃O}

O funk tem a influência das expressões musicais africanas e chegou ao Rio de Janeiro na década de 1970. Primeiro, os subgêneros enfatizavam variações que iam do romântico ao pornográfico, sem deixar de lado o estilo proibidão - em que, na maioria das vezes, o apelo político-social era destacado. Também por isso, foi associado à periferia e aos bailes funks das favelas cariocas. O estilo musical ganhou novas vertentes (por volta de meados de 2009). Nesse período, chega-se ao denominado funk ostentação - também conhecido como funk paulistano (PINHEIRO; RODRIGUES, 2013). Como relatado antes, o gênero ostentação é o foco deste estudo. Suas letras e sua forma de citar o status social a partir do dinheiro, do poder, de roupas de luxo e de grifes de marcas famosas e globalizadas integram a análise.

A globalização também será abordada a partir do viés do consumo, considerando-se que marcas internacionais tendem a provoca-lo a partir de sua influência e dos resultados que a ostentação do luxo busca, principalmente, em uma juventude que, sem condições financeiras, vê nas letras das músicas uma forma de inclusão social. Em resposta ao funk ostentação será analisada ainda uma música que tem a batida do funk, mas é ritmada com a ajuda de um violão e tem autoria de Edu Krieger ${ }^{3}$. A canção recrimina esse gênero musical quando, em suas letras, tende a incentivar o consumo e a ostentação. Krieger acredita que essa influência prospectada sobre a juventude carrega uma falsa promessa de inclusão social e também a ideia de uma equiparação do status social de diferentes classes.

Os apontamentos serão feitos com o auxílio da análise de discurso, embasada em Charaudeau (2014), tendo como objetivo o detalhamento das letras das duas músicas e a identificação dos elementos que caracterizam o poder de consumo como forma de vender uma promessa de inclusão social (com alusão às marcas de luxo e grifes). O aporte teórico terá como base os estudos de Bauman $(1999,2005)$ e Lipovetsky $(2004,2011)$ com suas abordagens e pesquisas relacionadas ao consumo e aos reflexos de nossa sociedade contemporânea.

\section{SOCIEDADE DE CONSUMO}

Numa sociedade de consumo que funcione de forma adequada, os consumidores buscam com todo o empenho ser seduzidos (BAUMAN, 1999, p. 92).

Assim como na epígrafe acima, em suas dezenas de obras, Bauman (1999) afirma que, numa sociedade de consumo que funcione de forma satisfatória, os indivíduos caracterizados como consumidores desejam a todo instante ser seduzidos. Eles querem ser atraídos pelo desejo de consumir objetos, estilos e comportamentos. Nessa linha tênue, parecem buscar uma maneira de serem aceitos ou mesmo de serem incluídos em nossa sociedade. Por esse motivo, em alguns casos, os bens materiais se tornam cartões de visita e promessas de um status social.

$\mathrm{Na}$ sociedade de consumo, ainda segundo Bauman (1999), os consumidores devem estar em movimento constante, sempre em busca de novos e efêmeros produtos, à procura de novos desejos,

\footnotetext{
${ }^{3}$ Eduardo Lyra Krieger tem como nome artístico Edu Krieger. Nascido no Rio de Janeiro em 5 de fevereiro de 1974, é compositor, instrumentista e cantor. Atualmente reconhecido como um dos mais talentosos da atual geração da música popular brasileira, Edu Krieger atraiu críticas e elogios ao vídeo Resposta ao Funk Ostentação. Insatisfeito com a popularidade da vertente paulista do gênero que tomou conta das pistas e das rádios brasileiras, o músico carioca comprou briga com os MCs propagadores de joias, carros, beldades e visualizações no YouTube. O vídeo foi lançado em agosto de 2014 e já foi visto mais de 1,2 milhão mil vezes. Disponível em: <https://www.youtube.com/watch?v=4aJwV8cWxDM>. Acesso em: 5 abr. 2017.
} 
transformados novamente em produtos. Ou seja, ao serem adquiridos, logo impulsionam o movimento de descarte para que novos desejos possam surgir e novos produtos sejam adquiridos, num ciclo permanente de 1) comprar, 2) usar e 3) rejeitar. Mas, para que isso funcione de maneira adequada, nesse movimento por vezes frenético, em que quanto mais rápido melhor, o consumidor desejado pela lógica consumista deve ser ávido. Ele é utilizado como mola propulsora e nunca deve ficar parado no tempo, correndo o risco de ser considerado um consumidor falho.

Esse consumidor - falho ou desatualizado -, é assim adjetivado porque, em sua maioria, não quer e/ou não deseja parecer. As empresas especialistas em estratégias de marketing, por outro lado, fazem de tudo para ajudar e informar a seus consumidores que seus produtos com suas respectivas marcas foram criados para contribuir com a pertença social. Os produtos, então, estariam a serviço dos objetivos de inclusão do consumidor. Nessa perspectiva do movimento de consumo, Bauman (1999, p. 93), pondera que "[...] a chegada tem esse cheiro mofado de fim de estrada, esse gosto amargo de monotonia e estagnação que poria fim a tudo aquilo pelo que e para que vive o consumidor". Em complemento, pode-se afirmar, ainda, que vivemos em uma sociedade bastante diferente da dos nossos ancestrais em que os homens trabalhavam para viver ou viviam para trabalhar. Em nossos tempos atuais, pode-se cogitar que hoje os indivíduos vivem para consumir - ou para poder consumir (BAUMAN, 1999).

A partir dos argumentos de Bauman (1999), é possível retomar a problematização deste estudo - quando são colocadas em destaque as letras das duas músicas já referidas: uma do gênero do funk ostentação (oriundo da exibição de produtos e objetos de marcas e grifes de luxo) e outra na contraposição desses versos cantados e exaltados por MCs que valorizam o dinheiro e tudo que ele compra. O funk ostentação, saliente-se, anuncia e vende em seu discurso o que chamamos de uma falsa promessa de inclusão e status social, que, segundo as composições, poderiam ser conquistados justamente pelo consumo dos objetos de luxo e de marcas famosas.

\section{O DESEJO DE CONSUMIR MARCAS GLOBALIZADAS E A VONTADE DE ATINGIR UM STATAUS SOCIAL}

Todo mundo por ser lançado na moda do consumo; todo mundo pode desejar ser um consumidor e aproveitar as oportunidades que esse modo de vida oferece. Mas nem todo mundo pode ser um consumidor. Desejar não basta; para tornar o desejo realmente desejável e assim extrair prazer do desejo, deve-se ter uma esperança racional de chegar mais perto do objeto desejado (BAUMAN, 1999, p. 94).

O parágrafo acima, de autoria de Bauman (1999), corrobora com a ideia dos desejos - de estar na moda, de poder consumir, de ter condições financeiras para se tornar um legítimo consumidor. Somente dessa forma é que esse sujeito poder ter a chance de aproveitar todas as oportunidades que lhe surgirem, não apenas desejando, mas adquirindo os objetos sonhados.

Outra tendência, abordada por Lipovetksy (2004) quando trata do consumo em nossas sociedades contemporâneas, sugere que os indivíduos tendem a afirmar sua identidade por meio do que consomem - considerando-se que, nessa perspectiva, há uma gama interminável de produtos simbólicos e que podem contribuir para que esses sujeitos façam suas escolhas sociais e de identidade a partir dos objetos, que garantiriam assemelharem-se a outros (pessoas, personagens) e permitiriam circular por determinados ambientes sociais com marcas que ajudam a caracterizar tribos e estilos. As marcas de luxo e grifes, além de demarcar o lugar de pertença de quem as utiliza, anuncia o poder aquisitivo desde a etiqueta até a explícita imagem da marca $(\operatorname{logo})$. 
O consumo desses bens materiais e a consequente divulgação das marcas geram esse valor simbólico, embolsado pelas grandes companhias. Klein (2000) inclusive destaca que os logotipos, até o início dos anos 1970, eram discretos e ficavam escondidos no lado avesso das roupas. Todavia, no final dessa década, imagens como a do cavaleiro da marca Polo e o crocodilo da Lacoste já podiam ser vistos estampados orgulhosamente nas roupas das pessoas pelas ruas. Klein (2000) também afirma que os logotipos surgiram como uma afetação ostentatória de um acessório de moda - a partir da função social da etiqueta. Ao exibir o logo, o sujeito estaria ostentando o alto valor financeiro investido por ele. Assim, ostentaria seu ethos dentro de seu contexto social.

Diante disso, recorremos a Campbell (2006) e a seu artigo intitulado Eu compro, logo sei que existo: as bases metafisicas do consumo moderno: "Que fique bem claro que não estou sugerindo que a identidade deriva de um produto ou serviço consumado, ou que, conforme dizem, as pessoas são aquilo que compram. É evidente que o que compramos diz algo sobre quem somos" (CAMPBELL, 2006, p. $56)$.

O que se compra - ou o que se deseja comprar - pode dizer algo sobre nós, inclusive quando já de posse de tais bens, já que o desejo de querer parecer ou de se mostrar diante dos outros revela nossas intenções. Pode-se, de forma consciente ou inconsciente, querer parecer e querer se tornar igual diante de quem se almeja ser. Talvez, nessa ocasião, esse desejo de posse de bens materiais possa ser interpretado como uma alusão ao imaginário de pertença.

Nosso objetivo, saliente-se, é problematizar as demonstrações e ostentações detalhadas nas letras de música do gênero funk ostentação. Essas canções retratam o consumo a partir de uma promessa de igualdade, focada em bens materiais e suas respectivas marcas. Nas composições, a maioria das marcas citadas são globais - conhecidas e reconhecidas internacionalmente. A ênfase é para o desejo eminente de possui-las e, assim, consequentemente, fixar-se em determinado espaço social. É nesse âmbito que se pode pontuar as questões relacionadas à globalização.

Para Bauman (1999), inclusive, em um mundo globalizado as esferas econômicas engrenam para uma produção de produtos obsoletos e voláteis. Segundo o autor, quem se restringe ao consumo de marcas nacionais - em tempos de um mundo globalizado -, passa a ser caraterizado como um sujeito privado e em degradação social. Ao pensar que consumidores estão se tornando globalizados, Zygmunt Bauman (1999) enfatiza que, para que sejam felizes, o caminho a eles ofertado passa globalização: mais opções, mais investimento, mais destaque. Por outro lado, aos consumidores com menor poder aquisitivo essa mesma globalização pode ser a causa da infelicidade.

Para os consumidores com menor poder aquisitivo ou com poder aquisitivo restrito, desejar bens materiais de marcas famosas e luxuosas é adentrar em um imaginário de falsas expectativas e de alusão à igualdade. O consumo material permitiria chegar mais próximo dos outros, mas, nessa situação, os que têm poder aquisitivo maior estão ainda mais distantes. Logo, a ostentação de itens vendidos por marcas de luxo e por grifes reconhecidas só engrossa ainda mais as fronteiras dos desiguais (financeiramente) existentes na sociedade de consumo que, além de irregular, propaga um discurso falso de inclusão e status social - explícito nas letras do funk ostentação.

\section{METODOLOGIA}

A metodologia aqui utilizada segue as recomendações de Prodanov e Freitas (2013). Parte-se de uma pesquisa exploratória com abordagem qualitativa, guiada pela análise do discurso contido em duas letras de música do gênero funk ostentação. Dá-se ênfase à letra do compositor e cantor Edu Krieger, 
que alterna sua posição de locutor para receptor por meio de pressupostos teóricos da análise do discurso. Cabe destacar que, neste estudo, o locutor (sujeito falante) se figura nas letras de Edu Krieger tendo como receptor (interlocutor) os cantores (MCs) do gênero do funk ostentação. Reitere-se que será analisado pelas letras do MC Boy do Charme, sem deixar de destacar os ouvintes (em sua maioria jovens) deste estilo musical.

Dessa forma, analisaremos, conforme definição de Charaudeau $(2014$, p. 67), "[...] o ato de comunição como um dispositivo cujo centro é ocupado pelo sujeito falante (o locutor, ao falar ou escrever), em relação com um outro parceiro (o interlocutor)." As categorias de análise são: $1^{\circ}$ ) O discurso do uso de marcas famosas e de luxo como forma de vender uma falsa promessa de igualdade e inclusão social - letra da música do Mc Boy do Chame e $2^{\circ}$ ) Não é pelos bens materiais que se conquista status, igualdade e inclusão social - letra da música de Edu Krieger.

A escolha dessas músicas deu-se em razão da repercussão obtida nas mídias, especialmente pela letra de Resposta ao funk ostentação, em que o compositor faz duras críticas aos compositores das letras de funk quando estes disseminam a ideia de que ostentar roupas, carros e bens de consumo em geral pode diminuir as desigualdades sociais. As composições são dirigidas justamente para as pessoas com menor poder aquisitivo que são, em grande parte, moradores de favelas - questão destacada logo no primeiro refrão da música de MC Boy do Charme.

\section{RESULTADO E ANÁLISE DO DISCURSO DAS LETRAS DE DUAS MÚSICAS DE FUNK}

As músicas do gênero funk ostentação vêm ganhando destaque nas mídias brasileiras. Suas letras carregam os nomes de diversas marcas de grife nacionais e internacionais e orientam para o consumo dessas marcas globalizadas, vendendo quase que um estilo de vida da nossa sociedade contemporânea. A partir disso, faremos uma abordagem de duas dessas músicas desde o viés da análise do discurso, com resultados parciais, visto que seria impossível dar conta de uma análise abrangente e que configurasse um resultado total, justificado pela ambivalência de possibilidades e riqueza dos dados, ou seja, de suas melodias e seus enunciados.

Diante de todo o glamour e sucesso ostentados pelos MCs e narrados nas letras de suas músicas, enfatizam-se ainda mais as desigualdades sociais, que são mais cruéis quando medidas pela régua do consumo de luxo. O sucesso e o glamour, nesses casos, são demonstrados tanto nas letras quanto nos videoclipes divulgados em diversas mídias. Em ambos, a felicidade e o sucesso profissional estão ligados ao ato de ostentar seus bens materiais de luxo.

$\mathrm{Na}$ busca de dados sobre as inspirações das letras do gênero musical, chegou-se à entrevista concedida pelo MC Boy do Charme ao apresentador Danilo Gentilii ${ }^{4}$ Quando questionado sobre qual seria a melhor definição para falar sobre o funk ostentação o cantor foi categórico: "É a realidade de alguns e a vontade de outros". Com essa declaração, fica ainda mais evidente o fator da desigualdade. Essas músicas não auxiliam na diminuição das diferenças. Pelo contrário, fomentam a ilusão de que a igualdade se combate pelo desejo e pela aquisição de produtos de grifes e de luxo.

Já a letra da música composta por Edu Krieger pode ser encontrada no blog da $\mathrm{Globo}^{5}$, onde o músico também argumenta que a badalação e a alusão desenfreada ao consumo - orientada pela aquisição de carrões, roupas de grife, cordões de ouro - só fazem aumentar a lacuna das diferenças.

\footnotetext{
4 A entrevista foi exibida em 24 de agosto de 2012 no programa Agora é tarde. Site oficial disponível em: <www.band.uol.com.br/agoraetarde/default.asp>. Acesso em: 9 jun. 2016.

5 Entrevista divulgada em setembro de 2014 no Blog da Globo: Disponível em: <http://blogs.oglobo.globo.com/ amplificador/post/a-batalha-da-ostentacao-edu-krieger-desperta-ira-dos-funkeiros-548048.html>. Acesso em: 9 jun. 2016.
} 
Minha música é um manifesto pró-negro, pró-periferia. Propõe um despertar para esses músicos, para que eles não sejam inocentes úteis. Acho que a exposição desse tipo de comportamento na mídia e nas redes sociais influencia as ambições e desejos dos jovens, que passam a ter uma falsa noção de que é mais importante ter do que ser. É um mau exemplo. E quando isso entra no âmbito da arte, é disseminado de uma maneira muito mais intensa. $\mathrm{O}$ resultado é muito ruim.

Esses músicos são vistos como famosos. E, para Bauman (1999), é em situações como essas que se pode afirmar que "[...] muitos observam poucos. Os poucos que são observados são as celebridades" (BAUMAN, 1999, p. 61). Os cantores são como locutores e vendem suas próprias imagens. Já os muitos que os observam são os fãs, admiradores de tais músicas. Pode-se afirmar que estes últimos ficam propensos a desejar os estilos e até mesmo as identidades dos cantores famosos - neste caso a de MC Boy do Charme, revelada na letra Nós de nave.

Já os muitos que escutam a música de Edu Krieger (Resposta ao funk ostentação) podem refletir de forma diferente - como o compositor propõe. A partir desse pensamento, a inclusão social poderia se tornar mais tangível.

Abaixo, no Quadro 1, a íntegra das duas músicas. Na sequência, depois desse detalhamento, damos início à avaliação das duas categorias de análise - como pontuamos, pelo viés do discurso inspirado em Charaudeau (2014).

Quadro 1 - Letras das músicas na íntegra com grifos do autor

\begin{tabular}{|c|c|}
\hline Nós de nave / MC Boy do Charme & Resposta ao funk ostentação / Edu Krieger \\
\hline $\begin{array}{l}\text { Imaginei, sorrindo eu tô na favela } \\
\text { Sou robbin hood, eu mato e morro por ela } \\
\text { Sei que a inveja continua rodiando a gente } \\
\text { Sou sofredor, mas tô botando ai na chapa quente. } \\
\text { Eu consegui comprar minha linda XT } \\
\text { O meu Megane e a } 1100 \text { tá vindo por aê } \\
\text { Fui imaginando, e quem imagina levanta a mão } \\
\text { Por ser humilde eu tenho um sonho e não é em vão } \\
\text { Vamo imaginando nóis de Porsche ou de Mercedes Benz } \\
\text { De Captiva, de BMW ou de } 1100 \\
\text { Vamo imaginando nóis de Porsche ou de Mercedes Benz } \\
\text { De Captiva, de BMW ou de } 1100 \\
\text { Toda semana a gente de rolé no shopping } \\
\text { Meu tênis novo Adidas, Nike ou pisante da Oakley } \\
\text { Blusa Abercrombie ou então a marca da Hollister } \\
\text { Eu de Armani ou Brooksfield e a polo da Lacoste } \\
\text { Relógio novo no pulso tem meu eco drive } \\
\text { Parando tudo de cordão, tô invadindo os bailes } \\
\text { Chandon na mesa, quando estoura cola as menina } \\
\text { Ostentação nóis leva a vida nessa ousadia } \\
\text { Vamo imaginando nóis de Porsche ou de Mercedes Benz } \\
\text { De Capitiva, de BMW ou de } 1100 \\
\text { Vamo imaginando nóis de Porsche ou de Mercedes Benz } \\
\text { De Capitiva, de BMW ou de } 1100 .\end{array}$ & $\begin{array}{l}\text { Você ostenta o que não tem } \\
\text { Pra tentar parecer mais feliz } \\
\text { Mas não sabe que pra ser alguém } \\
\text { Tem que agir ao contrário do que você diz } \\
\text { Você pensa que tem liberdade } \\
\text { Exibindo riqueza e poder } \\
\text { Mas não vê que na realidade } \\
\text { O sistema é que lucra usando você } \\
\text { E o sistema tem a cor } \\
\text { Do racismo e da escravidão } \\
\text { Cada vez que você dá valor } \\
\text { À roupinha de marca e à ostentação } \\
\text { A elite burguesa e branca } \\
\text { Que é dona das lojas de grife } \\
\text { Se dá bem, pois você bota banca } \\
\text { Mas é o sistema que aumenta o cacife } \\
\text { Clipe norte-americano } \\
\text { De artista que faz hip hop } \\
\text { Você quer imitar por engano } \\
\text { Pensando que assim vai ganhar mais ibope } \\
\text { É a regra do capitalismo } \\
\text { Eles querem que a gente consuma } \\
\text { Pra vivermos à beira do abismo } \\
\text { A gente pra eles é porra nenhuma } \\
\text { Pras crianças da comunidade }\end{array}$ \\
\hline
\end{tabular}




\begin{tabular}{|c|c|}
\hline Nós de nave / MC Boy do Charme & Resposta ao funk ostentação / Edu Krieger \\
\hline & 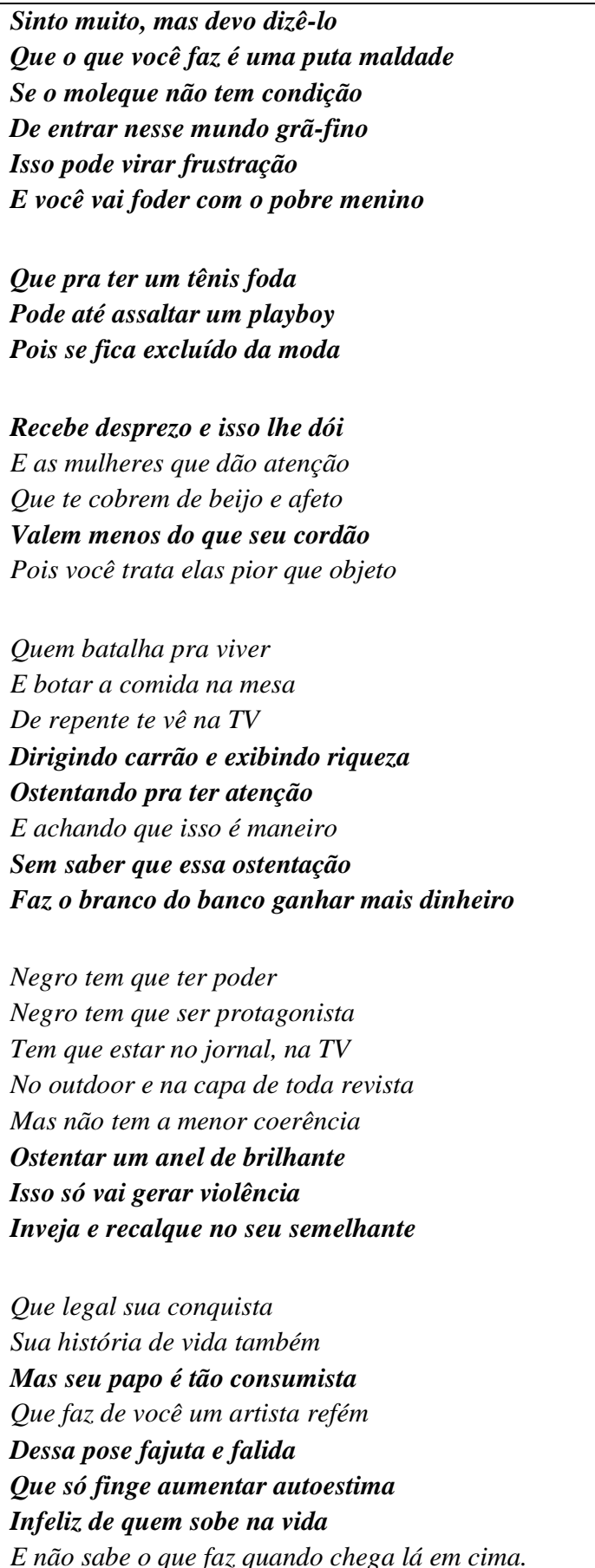 \\
\hline
\end{tabular}

Fonte: Os autores

No Quadro 2, a seguir, as duas categorias são identificadas pelos elementos que caracterizam a questão de desigualdade social.

Quadro 2 - Trechos extraídos das letras das músicas

\begin{tabular}{|l|l|}
\hline \multicolumn{2}{|c|}{ Categorias de análise } \\
\hline Nós de nave - MC Boy do Charme (o interlocutor) & $\begin{array}{l}\text { Resposta ao funk ostentação - Edu Krieger (o locutor, ao } \\
\text { falar ou escrever) }\end{array}$ \\
$\begin{array}{l}1^{\circ} \text { Categoria de análise: } \\
\text { uma discurso do uso de marcas famosas e de luxo para vender }\end{array}$ & $\begin{array}{l}2^{\circ} \text { Categoria de análise: } \\
\text { Não é pelos bens materiais que se conquista status, igualdade, } \\
\text { e inclusão social }\end{array}$ \\
\hline
\end{tabular}




\begin{tabular}{|c|c|}
\hline \multicolumn{2}{|c|}{ Categorias de análise } \\
\hline $\begin{array}{l}\text {-Eu consegui comprar minha linda XT } \\
\text { O meu Megane e a } 1100 \text { tá vindo por aê } \\
\text { - Vamo imaginando nóis de Porsche ou de Mercedes } \\
\text { Benz /De Captiva, de BMW ou de } 1100 \\
\text { - Meu tênis novo Adidas, Nike ou pisante da Oakley } \\
\text { Blusa Abercrombie ou então a marca da Hollister } \\
\text { Eu de Armani ou Brooksfield e a polo da Lacoste } \\
\text { Relógio novo no pulso tem meu eco drive } \\
\text { Parando tudo de cordão, tô invadindo os bailes } \\
\text { Chandon na mesa, quando estoura cola as menina } \\
\text { Ostentação nóis leva a vida nessa ousadia }\end{array}$ & $\begin{array}{l}\text { - Você ostenta o que não tem /Pra tentar parecer mais feliz } \\
\text { - Você pensa que é modelo /Pras crianças da comunidade } \\
\text { Sinto muito, mas devo dizê-lo /Que o que você faz é uma puta } \\
\text { maldade / Se o moleque não tem condição } \\
\text { De entrar nesse mundo grã-fino / Isso pode virar frustração } \\
\text { E você vai foder com o pobre menino } \\
\text { - Que pra ter um tênis foda / Pode até assaltar um playboy/ } \\
\text { Pois se fica excluído da moda } \\
\text { - Você quer imitar por engano /Pensando que assim vai } \\
\text { ganhar mais ibope / É a regra do capitalismo / Eles querem } \\
\text { que a gente consuma /Pra vivermos à beira do abismo/A } \\
\text { gente pra eles é porra nenhuma }\end{array}$ \\
\hline
\end{tabular}

Fonte: Os autores

A primeira categoria de análise surge na letra de Nós de nave. Nela, o funkeiro demonstra total orgulho de suas conquistas, sendo elas de bens materiais e ostentadas por marcas de grife e de luxo. Isso pode caracterizar uma evidência do que Lipovetsky (2011) designa como cultura hedonista, que incita a satisfação imediata das necessidades, quando enaltece o prazer em conquistas pessoais e de sucesso. Neste sentido, MC Boy do Charme se coloca em um pedestal, como se vivesse num paraíso (cabe destacar que a música menciona o seu lugar de origem - a favela -, contextualizando que está feliz e sorrindo), em que se diverte e consome sem parar.

$\mathrm{Na}$ letra de Resposta ao funk ostentação, Krieger (segunda categoria de análise) faz duras críticas aos pensamentos enaltecedores dos funkeiros. Por isso, releva que as narrativas de MC Boy do Charme podem contribuir para a frustação de meninos de origem simples e moradores de favelas. Neste mundo imaginário, proposto nas letras, são apresentadas e cantadas visões de um mundo para serem apenas sonhadas.

As conquistas pessoais geram uma falsa impressão - a ilusão da inclusão a esferas sociais diferentes. A ostentação de bens materiais oriundos de grifes famosas tendem a fomentar uma realidade utópica e vender falsos sonhos, contextualizados por um uma visão de mundo muito distante da vivida pela maioria dos que ouvem esse estilo de música.

Os sonhos e visões de mundo, descritos nas letras das músicas, acabam por virar anúncios publicitários, cantados e enaltecidos. Neste "comércio", conseguem transitar em diferentes meios de comunicação, conforme Lipovetsky (2011, p. 31) discorre a seguir.

Chegamos ao momento em que a comercialização dos modos de vida não mais encontram resistências estruturais, culturais nem ideológicas; e em que as esferas da vida social e individual se reorganizam em fase do consumo haviam tido como consequência a criação do consumidor moderno, arrancando-o às tradições e arruinando o ideal de poupança; a última fase estendeu ao infinito o domínio do consumo.

Outra questão levantada na letra feita por Krieger vem da interpretação (segunda categoria de análise) de quando menciona a inclusão de igualdade em esfera social, na qual cantores funkeiros querem também se convencer de que estão realmente se mostrando superiores. Eles insistem na ideia de vencer na vida por meio dos bens materiais adquiridos. A crítica então deduz que esses estão entrando na regra do capitalismo de "gente importante" que quer criar uma sociedade de "gente que consume". No mesmo refrão premedita que, ao final, se chegará à beira de um abismo que divide "essa gente" - 
uma sociedade de elite branca. Já os demais consumidores são escravizados por esses movimentos de ostentação, que, segundo o compositor, "não valem porra nenhuma".

De outra forma, Bauman (1999) afirma que tanto pobres quanto ricos habitam uma mesma cultura, vivendo num mundo idealizado em benefício dos que têm dinheiro. $\mathrm{O}$ autor esclarece, ainda, que a pobreza e a desigualdade se agravam com o crescimento econômico, sendo que se intensifica a recessão e o não crescimento. "[...] recessão significa mais pobreza e menos recurso; mas o crescimento leva a uma exibição ainda mais frenética de maravilhas de consumo e assim prenuncia um abismo ainda maior entre o desejado e o real" (BAUMAN, 1999, p. 104).

\author{
E o sistema tem a cor \\ Do racismo e da escravidão \\ Cada vez que você dá valor \\ À roupinha de marca e à ostentação \\ A elite burguesa e branca \\ Que é dona das lojas de grife \\ Se dá bem, pois você bota banca \\ Mas é o sistema que aumenta o cacife
}

(trecho da música Resposta ao funk ostentação)

Ao discutirmos o refrão da música acima, especificamente as questões sobre racismo e escravidão (primeira categoria de análise), notamos que o consumismo vem ao encontro de um consumo ligado a marcas internacionais e a grifes, por isso legitima-se por aquisições diretamente ligadas à globalização. Segundo Bauman (1999, p. 79), "[...] a globalização deu mais oportunidades aos extremamente ricos de ganhar dinheiro mais rápido". No mesmo refrão ainda se debate que a ostentação caminha rumo a uma escravidão do consumo, com efeitos satisfatórios para o capitalismo. Diante de tal argumento, o discurso da melodia relaciona-se com o que Bauman (1999, p. 80) defende: "Os antigos ricos precisavam dos pobres para fazê-los e mantê-los ricos".

Para finalizar as análises, utilizamos as constatações de Pinheiro e Rodrigues (2013), quando descrevem que o funk ostentação reflete apenas o atual momento de indivíduos que, pelo consumo desmedido, buscam seu lugar e seu papel na sociedade. Esse momento ainda é descrito como o de viver o aqui e agora, sem grandes preocupações dos estilos adotados seja por aceitadores ou receptores, uma vez que a mensagem é a de ter para ostentar. Isso tudo pode gerar um paradoxo entre os que nasceram e/ou vivem nas favelas já que as letras só atingem ou dizem respeito àqueles que verdadeiramente possuem dinheiro para comprar e adquirir os objetivos listados nas inúmeras letras propagadas pelo funk ostentação.

\title{
6 CONSIDERAÇÕES FINAIS
}

Este estudo buscou problematizar as demonstrações e ostentações detalhadas nas letras de música do gênero funk ostentação o que chamamos de uma falsa promessa de inclusão e status social, que, segundo as análises presentes nesta pesquisa tendem a induzir uma falsa interpretação a quem as escuta. Uma das melodias evidencia uma falsa forma de inclusão social por meio da ostentação de bens de consumo - esses, em sua maioria, de marcas internacionais caraterizadas por grifes famosas de luxo. Já a outra composição surge com o intuito de criticar e debater os estilos musicais do funk ostentação muito em voga em nossos tempos. As músicas, em muitos casos, têm como finalidade justamente a propagação 
do consumismo e a ostentação como forma de mascarar a realidade social vivida por parte dos MCs, antes da fama. As letras soam como ecos - em todos os cantos - do sucesso profissional/musical obtidos pelo escancaramento do luxo e do consumo extremo.

Diante desta problemática, surgiram as categorias de análise. Para que fossem possíveis as análises dos discursos que continham o uso ampliado de marcas como promessa de diminuir uma desigualdade social, foram confrontadas as melodias da música Nós de nave e Resposta ao funk ostentação - que, por sua vez, coloca em ênfase a falsa promessa de que a felicidade pode ser conquistada por meio de uma vida consumista visando somente o prazer pessoal e hedonista por parte dos MCs do funk ostentação.

São levantadas hipóteses de que essas falsas promessas tendem a criar frustações ainda maiores em muitos jovens que têm poder financeiro desigual, sendo impossível para eles o sonho de usufruir de tais conquistas. As letras, a todo instante, instigam a um pensamento de felicidade e a uma vida melhorada pelo luxo e pelo consumismo desenfreado. Isso não ajuda na criação de uma ação social em busca de igualdade. Ao contrário, coloca os jovens da periferia em lugar ainda mais distante quando os ilude com a ideia de igualdade social e status adquirido por meio do consumo de determinadas marcas.

As letras do funk ostentação podem ainda vir a contribuir para uma conjectura negativa e consequências desastrosas como, por exemplo, o aumento do número de jovens no mundo crime em busca de legitimidade de suas realizações pessoais e de prazeres individuais e hedonistas, por meio de conquistas de bens de luxo como forma de ostentar um estilo de vida e uma falsa inclusão e status social.

Acredita-se ainda na relevância da promoção de discussões a este respeito, em que coloca-se em pauta o pensamento acerca de uma sociedade de consumidores, que se (re)constroem à medida que se propagam afirmações diárias de que a felicidade pessoal pode e está ligada ao poder de consumo e, ainda, a de estar se movimentando e/ou consumindo cada vez mais rápido em busca de produtos e seus valores simbólicos para conquistar espaços em uma sociedade contemporânea e consumista.

Sociedade essa em que, muitas vezes, o valor dado às pessoas é atribuído pelo que possuem ou que ainda possam obter tão somente pela sua conta monetária. Alguns questionamentos não findam com essas últimas linhas. Novas perguntas e inquietações podem vir a contribuir em outros estudos: poderiam estar imbuídos em letras de funk ostentação valores como o da educação e da cultura como forma de uma coerente inclusão social e mais igualitária? Ou, ainda, como poderia se produzir valor a uma ostentação cultural e educacional em nossa sociedade, em que a maioria da população carente tem acesso à cultura tão somente por meio das mídias como televisão, rádio, jornal e, em alguns casos pela Internet - considerando-se que, infelizmente, por esses meios comunicacionais, o que se tem visto é a venda de um estilo de vida consumista e que pouco tem contribuído para ações reais de construção de pensamentos críticos e formas de debater a inclusão e a desigualdade em nossa sociedade que caminha a passos lentos na busca de igualdade social?

\section{REFERÊNCIAS}

BAUMAN, Zygmunt. Globalização: As Consequências Humanas. Tradução: Marcus Penchel. Rio de Janeiro: Zahar, 1999.

Identidade. Tradução: Carlos Alberto Medeiros. Rio de Janeiro: Zahar, 2005.

CAMPBELL, Colin. Eu compro, logo sei que êxito: as bases metafisicas do consumo moderno. In: BARBOSA, Lívia, Org. Juventude e Gerações no Brasil Contemporâneo. Porto Alegre: Sulina, 2012. p.47-64. 
CHARAUDEAU, Patrick. Linguagem e discursos: modos de organização. São Paulo. Ed. Contexto, 2014.

KLEIN, Naomi. Sem Logo: A Tirania das Marcas em um Planeta Vendido. Rio de Janeiro: Record. 2009.

KRIEGER, Eduardo. Resposta ao funk ostentação. Disponível em:

<https://www.youtube.com/watch?v=4aJwV8cWxDM>. Acesso em: 5 abr. 2017.

LIPOVETSKY, Gilles. Metamorfoses da Cultura Liberal. Tradução: Juremir Machado da Silva. Porto Alegre. Editora Sulina, 2004.

Os tempos Hipermodernos. Tradução: Mário Vilela. São Paulo. São Paulo. Editora Barcarolla, 2011.

PINHEIRO, Tatiana Ifran Mara; RODRIGUES, L. Marlon. Ideias Linguísticas Expressas Através do Discurso do Funk Ostentação. Disponível em:

<http://www.filologia.org.br/revista/57supl/51.pdf>. Acesso em: 12 abr. 2017.

PRODANOV, C. C.; FREITAS, E. C. de. Metodologia do trabalho científico: métodos e técnicas da pesquisa e do trabalho acadêmico. 2. ed. Novo Hamburgo: Feevale, 2013. Disponível em: $<$ http://docente.ifrn.edu.br/valcinetemacedo/disciplinas/metodologia-do-trabalho-cientifico/e-bookmtc>. Acesso em: 1 jun. 2016. 